$\mathrm{DOE} / \mathrm{MC} / 29228-3408$

\title{
SELECTIVE METHANE OXIDATION OVER PROMOTED OXIDE CATALYSTS
}

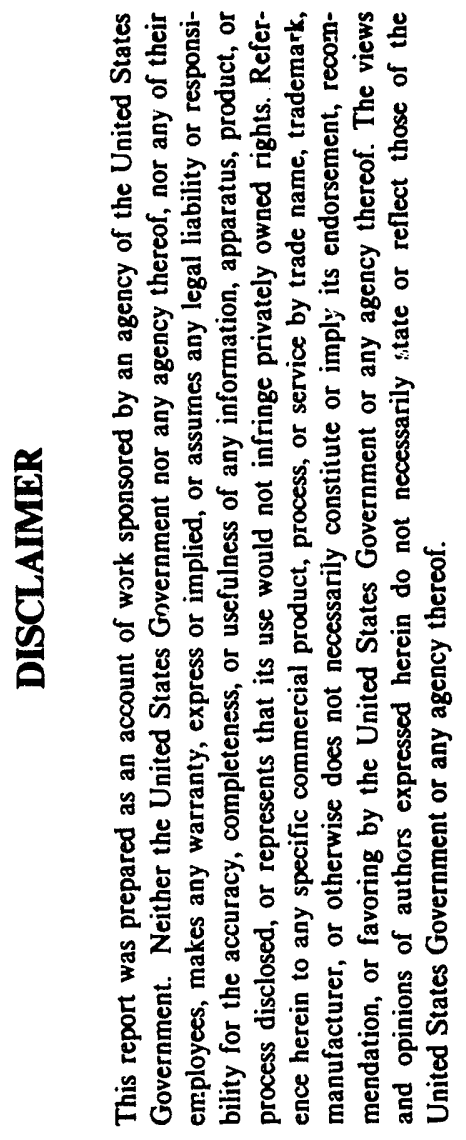

Quarterly Technical Progress Report

March 1, 1993-May 31, 1993

Kamil Klier and Richard G. Herman with

János Sárkány and Qun Sun

Zettlemoyer Center for Surface Studies

and

Department of Chemistry

Lehigh University

Bethlehem, PA 18015

June 1993

Prepared for

U.S. Department of Energy

Office of Fossil Energy

Morgantown Energy Technology Center

Morgantown, West Virginia 26507-0880

Under Contract No. DE-FG21-92MC29228

MASTER 


\section{DISCLAIMER}

This report was prepared as an account of work sponsored by the United States Government. Neither the United States nor the United States Department of Energy, nor any of their employees, makes any warranty, express or implied, or assumes any legal liability or responsibility for the accuracy, completeness, or usefulness of any information, apparatus, product or process disclosed, or represents that its use would not infringe privately owned rights. 


\section{SELECTIVE METHANE OXIDATION OVER PROMOTED OXIDE CATALYSTS}

\section{SUMMARY OF PROGRESS}

A $1 \mathrm{wt} \% \mathrm{SO}_{4}{ }^{2-} / 1 \mathrm{wt} \% \mathrm{Sr} / \mathrm{La}_{2} \mathrm{O}_{3}$ catalyst has been shown by us to be one of the most active catalyst for the oxidative coupling of $\mathrm{CH}_{4}$ to $\mathrm{C}_{2}$ hydrocarbons. One of the by-products is $\mathrm{CO}_{2}$ and this is a potential strong poison for the formation of $\mathrm{C}_{2}{ }^{+}$products. Hence, various pretreatments of this catalyst were studied in terms of effect on the catalytic performance. Before the reaction was carried out at 500 or $550^{\circ} \mathrm{C}$, the catalyst was pretreated in flowing air or $\mathrm{He}$ at 500,700 , or $800^{\circ} \mathrm{C}$. Relative to the $500^{\circ} \mathrm{C}$ treatment, the pretreatment in air at $700^{\circ} \mathrm{C}$ only slightly decreased the $\mathrm{C}_{2}^{+}$selectivity while the $\mathrm{CO}_{x}$ selectivity increased. This effect was larger when the pretreatment was carried out at $800^{\circ} \mathrm{C}$. Since the $\mathrm{CH}_{4}$ conversion also decreased in this latter case, it is probable that the high temperature treatment somewhat decreased the surface area of the catalyst. It was observed that the deactivation effect was slightly smaller when the pretreatments were carried out in $\mathrm{He}$ instead of air. For both air and $\mathrm{He}$, the $\mathrm{CH}_{4}$ conversion and the $\mathrm{C}_{2}$ \%yield showed more or less parallel changes (small decreases) with increasing pretreatment temperature.

After a standard pretreatment $\left(\right.$ air, $\left.500^{\circ} \mathrm{C}, 1 \mathrm{hr}\right)$, the reaction temperature was increased stepwise from 500 to $700^{\circ} \mathrm{C}$ and then lowered to 550 (or 500$)^{\circ} \mathrm{C}$. It was observed that the catalytic performance showed deactivation towards the $\mathrm{C}_{2}{ }^{+}$products. Although subsequent pretreatments in air at 500,600 , and $700^{\circ} \mathrm{C}$ resulted in some improvements in the catalytic activity and selectivity at $550^{\circ} \mathrm{C}$, the original catalytic features were not restorable, principally because of somewhat lower activity and higher selectivity toward $\mathrm{CO}_{\mathbf{x}}$.

Decreasing stepwise the total flow rate (GHSV) of the reacting gas mixture $\left(\mathrm{CH}_{4} /\right.$ air $=1 / 1)$ from 70,175 to $5,388 \mathrm{l} / \mathrm{kg}$ catal $/ \mathrm{hr}$ at a reaction temperature of $550^{\circ} \mathrm{C}$ caused large changes in both the activity and selectivity. For example, the $\mathrm{CH}_{4}$ concersion decreased by a factor of 2.27. In addition, the $\mathrm{C}_{2}{ }^{+}$selectivity and the $\mathrm{C}_{2}{ }^{+}$\%yield dramatically decreased, while the $\mathrm{CO}_{\mathrm{x}}$ selectivity increased. By subsequently increasing the flow rate, the catalytic conversion of methane increased, but it remained below the original values over the whole GHSV range, i.e. a residence-time-hysteresis was observed. These results indicate the importance of coupling of $\mathrm{CH}_{3}$ radicals in the gaseous phase and the formation of $\mathrm{CO}_{\mathbf{x}}$ byproducts in competitive gas phase reactions of $\cdot \mathrm{CH}_{3}$ radicals with $\mathrm{O}_{2}$. The higher contact time is less preferable for the formation of $\mathrm{C}_{2}{ }^{+}$products.

After going back at $550^{\circ} \mathrm{C}$ to the original GHSV $=70,175 \mathrm{l} / \mathrm{kg}$ catal $/ \mathrm{hr}$, the temperature was increased stepwise up to $600^{\circ} \mathrm{C}$. Up to $580^{\circ} \mathrm{C}$, the catalytic activity and selectivity did not change very much. However, at $585^{\circ} \mathrm{C}$ the $\mathrm{CH}_{4}$ conversion, $\mathrm{C}_{2}^{+}$selectivity, and \%yield of $\mathrm{C}_{2}{ }^{+}$jumped significantly to higher values, while the $\mathrm{CO}_{x}$ selectivity dropped. Upon further temperature increase to $600^{\circ} \mathrm{C}$, further slight improvement in the catalytic performance was observed. With subsequent decreasing temperature to $530^{\circ} \mathrm{C}$, the catalytic features were gradually reversed without sudden jumps, resulting in a temperature-hysteresis in the observed activity and selectivity of the catalyst at temperatures below $585^{\circ} \mathrm{C}$. Thus, activity and selectivity are recoverable by temperature treatment at $>585^{\circ} \mathrm{C}$ after apparent $\mathrm{CO}_{2}$ poisoning that occurs under the longer residence time (lower GHSV) conditions. 
SELECTIVE METHANE OXIDATION OVER PROMOTED OXIDE CATALYSTS

\section{OBJECTIVES OF THE RESEARCH}

The objective of this research is the selective oxidative coupling of methane to $C_{2}$ hydrocarbons (Equations 1-3) and oxygenates, in particular formaldehyde and methanol as represented by Equations 4 and 5. Air, oxygen, or carbon dioxide, rather than nitrous oxide will be utilized as the oxidizing gas at high gas hourly space velocity, but mild reaction conditions $\left(500-700^{\circ} \mathrm{C}, 1\right.$ atm total pressure). All the investigated process are catalytic, aiming at minimizing difficult to control gas phase reactions.

$\begin{array}{lllll}2 \mathrm{CH}_{4} & +1 / 2 \mathrm{O}_{2} & \mathrm{C}_{2} \mathrm{H}_{6}+\mathrm{H}_{2} \mathrm{O} \\ 2 \mathrm{CH}_{4} & + & \mathrm{O}_{2} & \mathrm{C}_{2} \mathrm{H}_{4}+2 \mathrm{H}_{2} \mathrm{O} \\ 2 \mathrm{CH}_{4} & + & 2 \mathrm{CO}_{2} & \mathrm{C}_{2} \mathrm{H}_{4}+2 \mathrm{CO}+2 \mathrm{H}_{2} \mathrm{O} \\ \mathrm{CH}_{4} & + & \mathrm{O}_{2} & \mathrm{CH}_{2} \mathrm{O}+\mathrm{H}_{2} \mathrm{O} \\ \mathrm{CH}_{4} & + & 1 / 2 \mathrm{O}_{2} & \end{array}$

Oxide catalysts are chosen for this research that are surface doped with small amounts of acidic dopants. It was proposed that, for example, the very basic $\mathrm{Sr} / \mathrm{La}_{2} \mathrm{O}_{3}$ catalyst that is active in the formation of methyl radicals, and therefore of $\mathrm{C}_{2}^{+}$products, can be doped with Lewis acidic oxides or other acidic groups to increase further its activity and selectivity to $\mathrm{C}_{2}$ products.

The research being carried out under this U.S. DOE-METC contract is divided into the following three tasks:

Task 1. Maximizing Selective Methane Oxidation to $\mathrm{C}_{2}^{+}$Products Over Promoted $\mathrm{Sr} / \mathrm{La}_{2} \mathrm{O}_{3}$ Catalysts.

Task 2. Selective Methane Oxidation to Oxygenates.

Task 3. Catalyst Characterization and Optimization.

Task 1 deals with the preparation, testing, and optimization of acidic promoted lanthana-based catalysts for the synthesis of $\mathrm{C}_{2}{ }^{+}$hydrocarbons. Task 2 aims at the formation and optimization of promoted catalysts for the synthesis of oxygenates, in particular formaldehyde and methanol. Task 3 involves characterization of the most promising catalysts so that optimization can be achieved under Tasks 1 and 2 . 


\title{
SELECTIVE METHANE OXIDATION OVER PROMOTED OXIDE CATALYSTS
}

\author{
RESEARCH PROGRESS
}

\author{
Oxidative Coupling of Methane Over Sulfate-Doped Sr/La $\mathrm{L}_{3}$ Catalysts
}

\section{Introduction}

It would be desirable to convert methane (a significant component of natural gas) to higher molecular weight products for transportation fuels, easier storage as liquids, and for utilization as chemical feedstock. Although this desire is not a new topic in the research, its importance increased very much in the last decade. After the first publication about catalytic coupling of methane in 1982 [1], many academic and industrial laboratories around the world make large efforts to find a commercial catalyst for methane conversion. Excellent reviews have appeared on this subject [2-11], and more than a hundred catalysts that exhibit activity for the oxidative transformation of $\mathrm{CH}_{4}$ to hydrocarbons or to oxygenates have been described. This number is still growing, but only a few of them are worthwhile to study in more detail.

The catalysts based on rare-earth oxides are among the most promising as they simultaneously present good selectivity to $\mathrm{C}_{2}^{+}$products, high activity, good stability at reaction conditions, and a relatively low cost. The strontium-doped $\mathrm{La}_{2} \mathrm{O}_{3}$ is one of the best known catalysts [12-14], which results in even a better catalytic performance than the pure oxide.

It was found that the catalytic features of the very basic $\mathrm{Sr} / \mathrm{La}_{2} \mathrm{O}_{3}$ catalyst were improved by surface doping with sulfate. Indeed, compared with the activity of the nonsulfated $1 \mathrm{wt} \% \mathrm{Sr} / \mathrm{La}_{2} \mathrm{O}_{3}$ catalyst, the $1-4 \mathrm{wt} \% \mathrm{SO}_{4}{ }^{2-} / \mathrm{Sr} / \mathrm{La}_{2} \mathrm{O}_{3}$ catalyst resulted in enhancement of the methane conversion, the $\mathrm{C}_{2}$ selectivity, and the \%yield of $\mathrm{C}_{2}$ products by factors of 1.7-2.0, 1.5-1.9, and 2.2-3.9, respectively [15]. It was observed that a 1 wt\% sulfate content, initially doped onto the surface of the catalyst, yielded the be'st catalytic performance when using a $\mathrm{CH}_{4} /$ air $=1 / 1$ reactant mixture at $1 \mathrm{~atm}$ and with a gas hourly space velocity $(\mathrm{GHSV})=70,000 \mathrm{\ell} / \mathrm{kg}$ catal $/ \mathrm{hr}$.

In this quarterly progress report, the effects of (a) catalyst pretreatment and (b) flow rate of the reactant gas mixture on the catalytic features of the $1 \mathrm{wt} \% \mathrm{SO}_{4}{ }^{2-} / 1 \mathrm{wt} \%$ $\mathrm{Sr} / \mathrm{La}_{2} \mathrm{O}_{3}$ catalyst are reported.

\section{Experimental}

The $1 \mathrm{wt} \% \mathrm{Sr} / \mathrm{La}_{2} \mathrm{O}_{3}$ catalyst with a surface area of $6.5 \mathrm{~m}^{2} / \mathrm{g}$ was obtained from Amoco Oil Co. under their Natural Gas University Research Program. The sulfated $\mathrm{Sr} / \mathrm{La}_{2} \mathrm{O}_{3}$ catalysts were produced by the incipient wetness impregnation technique. The appropriate amount of $\left(\mathrm{NH}_{4}\right)_{2} \mathrm{SO}_{4}$ was dissolved in deionized water, the measured quantity of $\mathrm{Sr} / \mathrm{La}_{2} \mathrm{O}_{3}$ was added, and the slurry was continuously stirred with a magnetic stirrer until 
dryness was achieved. This was followed by drying the solid at $121^{\circ} \mathrm{C}$ overnight and then calcination in air at $600^{\circ} \mathrm{C}$ for $6 \mathrm{hr}$. Prior to catalytic testing, the samples were activated in situ under air flow at $500^{\circ} \mathrm{C}$ for $1 \mathrm{hr}$ (standard pretreatment), or at higher temperatures $\left(600,700\right.$, and $\left.800^{\circ} \mathrm{C}\right)$ in air or $\mathrm{He}$ (new pretreatments). The gases used in this study were zero grade purity and were used without any purification.

Catalytic testing was carried out in the temperature range of $500-700^{\circ} \mathrm{C}$ in a fixed-bed continuous-flow $9 \mathrm{~mm}$ OD ( $7 \mathrm{~mm} \mathrm{ID)} \mathrm{quartz} \mathrm{reactor} \mathrm{using} 0.1000 \mathrm{~g}$ of catalyst. Generally, a reaction mixtures of $\mathrm{CH}_{4} /$ air $=1 / 1$ was used at ambient pressure and at high total flow rate (GHSV $=70,000 \mathrm{\ell} / \mathrm{kg} \mathrm{catal} / \mathrm{hr}$ ). In other experiments, the GHSV was also varied while the gas composition was kept constant, i.e. $\mathrm{CH}_{4} /$ air $=1 / 1$. The principal products analyzed by on-line sampling using gas chromatography were $\mathrm{CO}_{2}, \mathrm{C}_{2}\left(\mathrm{C}_{2} \mathrm{H}_{6}+\mathrm{C}_{2} \mathrm{H}_{4}\right), \mathrm{C}_{3}$ $\left(\mathrm{C}_{3} \mathrm{H}_{8}+\mathrm{C}_{3} \mathrm{H}_{6}\right), \mathrm{CO}$, and $\mathrm{H}_{2} \mathrm{O}$. The carbon mass balance during the catalytic reaction was better than $95 \%$.

\section{Results and Discussion}

\subsection{Effect of Pretreatment}

\subsubsection{Standard Pretreatment}

In accordance with the earlier findings [15], the $1 \mathrm{wt} \% \mathrm{SO}_{4}{ }^{2-} / 1 \mathrm{wt} \% \mathrm{Sr} / \mathrm{La}_{2} \mathrm{O}_{3}$ catalyst showed partial deactivation when the reaction temperature was increased to $700^{\circ} \mathrm{C}$ in the gas mixture of $\mathrm{CH}_{4} /$ air $=1 / 1$ with a total flow rate (GHSV) of $70,000 \mathrm{\ell} / \mathrm{kg}$ catal $/ \mathrm{hr}$ followed by a decrease in the reaction temperature to 550 or $500^{\circ} \mathrm{C}$ (see also Table 1 , Experiments A and B). This deactivation is referred to as High-Temperature-CausedDeactivation (HTCD). It was unknown at that time whether the activity could be restored with additional pretreatment or not.

The HTCD-catalyst was pretreated before the new runs in flowing air (GHSV $35,000 \mathrm{\ell} / \mathrm{kg} \mathrm{catal} / \mathrm{hr}$ ) at 500,600 , and $700^{\circ} \mathrm{C}$, respectively (Table 1 ). For the reaction at $500^{\circ} \mathrm{C}$, these pretreatments did not improve the catalytic performance. For the reaction at $550^{\circ} \mathrm{C}$, the previous pretreatments in air resulted in some increases in both $\mathrm{CH}_{4}$ conversion and $\mathrm{C}_{2}{ }^{+}$selectivity and \%yield. However, the original activity could not be restored. Of the pretreatments, the highest performance was obtained when the sample was pretreated only at $500^{\circ} \mathrm{C}$ and not at higher temperatures. The extent of this improvement towards $\mathrm{C}_{2}^{+}$ production decreased as the temperature of pretreatment was increased.

Since HTCD was not observed for non-sulfated $1 \mathrm{wt} \% \mathrm{Sr} / \mathrm{La}_{2} \mathrm{O}_{3}$ catalyst [15], the obtained HTCD for $1 \mathrm{wt} \% \mathrm{SO}_{4}{ }^{2-} / 1 \mathrm{wt} \% \mathrm{Sr} / \mathrm{La}_{2} \mathrm{O}_{3}$ might be directly related to the $\mathrm{SO}_{4}{ }^{2-}$ content. The conversion of $\mathrm{O}_{2}$ in the reactant air was $90-95 \%$ in the reaction at $700^{\circ} \mathrm{C}$. Hence it is probable that, because of the reducing environment, some of the sulfate species was transformed to lower oxidation state(s) that might diffuse into the bulk or/and even leave the solid catalyst as a gas phase component. More experimental data, especially in terms of catalyst characterization, are needed to obtain a better understanding of the deactivation process. 


\section{TABLE 1}

Effects of reaction cycle and various pretreatments in air on the catalytic performance of the $1 \mathrm{wt} \% \mathrm{SO}_{4}{ }^{2-} / 1 \mathrm{wt} \% \mathrm{Sr} / \mathrm{La}_{2} \mathrm{O}_{3}$ catalyst $(0.1000 \mathrm{~g})$ in the oxidative coupling of $\mathrm{CH}_{4}$ (reaction mixture of $\mathrm{CH}_{4} /$ air $=1 / 1$; total pressure $=1 \mathrm{~atm}$; and GHSV $=70,000 \mathrm{e} / \mathrm{kg}$ catal/hr)

Reaction Temperature

$\left({ }^{\circ} \mathrm{C}\right)$
$\mathrm{CH}_{4}$ Conversion

(C-mol\%)
Product Selectivity

(C-mol\%)

$\mathrm{C}_{2+}$

$\mathrm{CO}_{x}$
Yield of $\mathbf{C}_{2+}$

(C-mol\%)

(A) After the 1st pretreatment (air, $500^{\circ} \mathrm{C}, 1 \mathrm{hr}$ - Standard Pretreatment)

$\begin{array}{lllll}500 & 16.77 & 41.37 & 56.77 & 6.94 \\ 550 & 20.16 & 49.40 & 48.82 & 9.96\end{array}$

(B) After a reaction cycle $500 \rightarrow 700 \rightarrow 550(500)^{\circ} \mathrm{C}$

$\begin{array}{lrrrr}500 & 3.85 & 11.55 & 86.52 & 0.45 \\ 550 & 14.03 & 37.12 & 60.75 & 5.21\end{array}$

(C) After the 2nd preteatment (air, $500^{\circ} \mathrm{C}, 1 \mathrm{hr}$ )

$\begin{array}{lrrrr}500 & 2.04 & 2.51 & 96.91 & 0.05 \\ 550 & 17.21 & 45.31 & 53.29 & 7.80\end{array}$

(D) After the 3rd pretreatment (air, $600^{\circ} \mathrm{C}, 4 \mathrm{hr}$ )

$\begin{array}{rrrrr}500 & 1.72 & 12.20 & 87.76 & 0.22 \\ 550 & 17.39 & 43.60 & 54.97 & 7.57\end{array}$

(E) After the 4 th pretreatment (air, $700^{\circ} \mathrm{C}, 1 \mathrm{hr}$ )

$\begin{array}{rrrrr}500 & 3.58 & 3.50 & 96.25 & 0.13 \\ 550 & 15.91 & 36.30 & 62.56 & 5.77\end{array}$

Note: The same catalyst was used in the entire experiment. 


\subsubsection{New Pretreatments}

Prior to carrying out the catalytic reaction at 500 and $550^{\circ} \mathrm{C}$, fresh samples were pretreated in air or $\mathrm{He}$ at 500,700 , and $800^{\circ} \mathrm{C}$. To simplify interpretation of the catalytic data, a new sample was used in each experiment.

Pretreatment in Air. Compared to the resuits obtained in the case of the standard pretreatment (air, $500^{\circ} \mathrm{C}, 1 \mathrm{hr}$ ), pretreatment in air at $700^{\circ} \mathrm{C}$ slightly increased the $\mathrm{CH}_{4}$ conversion and $\mathrm{CO}_{x}$ selectivity, but decreased the $\mathrm{C}_{2}{ }^{+}$selectivity at reaction temperatures of 500 and $550^{\circ} \mathrm{C}$ (Figures 1 and 2 , and Table 2). The pretreatment at $800^{\circ} \mathrm{C}$ caused a much larger decrease in the catalytic activity; where the $\mathrm{CH}_{4}$ conversion and the $\mathrm{C}_{2}^{+}$selectivity decreased, while $\mathrm{CO}_{x}$ selectivity increased. Again, the trends at both reaction temperatures were the same.

Pretreatment in He. Similar results were obtained in the case of He-pretreated samples (Figures 3 and 4, and Table 2), as for the air-treated ones. Pretreatment of the samples in $\mathrm{He}$ at $500^{\circ} \mathrm{C}$ did not show any differences in the catalytic performances at 500 or $550^{\circ} \mathrm{C}$, compared to those observed for the catalysts pretreated in air at $500^{\circ} \mathrm{C}$. Following the pretreatments in $\mathrm{He}$ at 700 or $800^{\circ} \mathrm{C}$, the changes in $\mathrm{CH}_{4}$ conversion, $\mathrm{CH}_{2}^{+}$and $\mathrm{CO}_{x}$ selectivities, and \%yield of $\mathrm{C}_{2}{ }^{+}$products obtained at the reaction temperatures of both 500 and $550^{\circ} \mathrm{C}$ followed the same trends as observed for the air-treated catalysts. The higher the temperature of pretreatment, the lower the catalytic performance towards the $\mathrm{CH}_{4}$ conversion and formation of $\mathrm{C}_{2}^{+}$products. The only small difference is that the pretreatment in $\mathrm{He}$ resulted in smoother changes in the catalytic parameters with increasing pretreatment temperature than those obtained in the case of air-treated samples.

It is known that surface carbonate on the catalyst may cause some extent of deactivation in the partial oxidation of methane [16-19]. In our case, the catalyst contains carbonates before and also after the standard pretreatment [15]. It is proposed that (a) the concentration of the surface carbonates should decrease with increasing pretreatment temperature, and (b) if there is any decomposition of $\mathrm{SO}_{4}{ }^{2-}$ during pretreatment, the use of an oxidizing atmosphere, e.g. air, should give more prevention against this decomposition than He. However, it is clear from Figures 1-4 and Table 2 that this is not the case, i.e. not only the $\mathrm{CH}_{4}$ conversion, but also the $\mathrm{C}_{2}{ }^{+}$selectivity decreased. These observations suggest that the carbonate existing on the catalyst surface before pretreatment should not be the most important factor in catalytic deactivation during the oxidative coupling of $\mathrm{CH}_{4}$ to $\mathrm{C}_{2}{ }^{+}$ products.

\subsection{Effect of Flow Rate}

\subsubsection{Deactivation - Effect of Residence Time}

The $1 \mathrm{wt} \% \mathrm{SO}_{4}{ }^{2-} / 1 \mathrm{wt} \% \mathrm{Sr} / \mathrm{La}_{2} \mathrm{O}_{3}$ catalyst was pretreated for these experiments in air at $500^{\circ} \mathrm{C}$ for $1 \mathrm{hr}$, then the methane conversion reaction was carried out at $550^{\circ} \mathrm{C}$. A new sample was used in each run, and the composition of the reactive gas mixture was kept constant $\left(\mathrm{CH}_{4} / \mathrm{Air}=1 / 1\right)$ while the total flow rate was varied. The reaction started with 


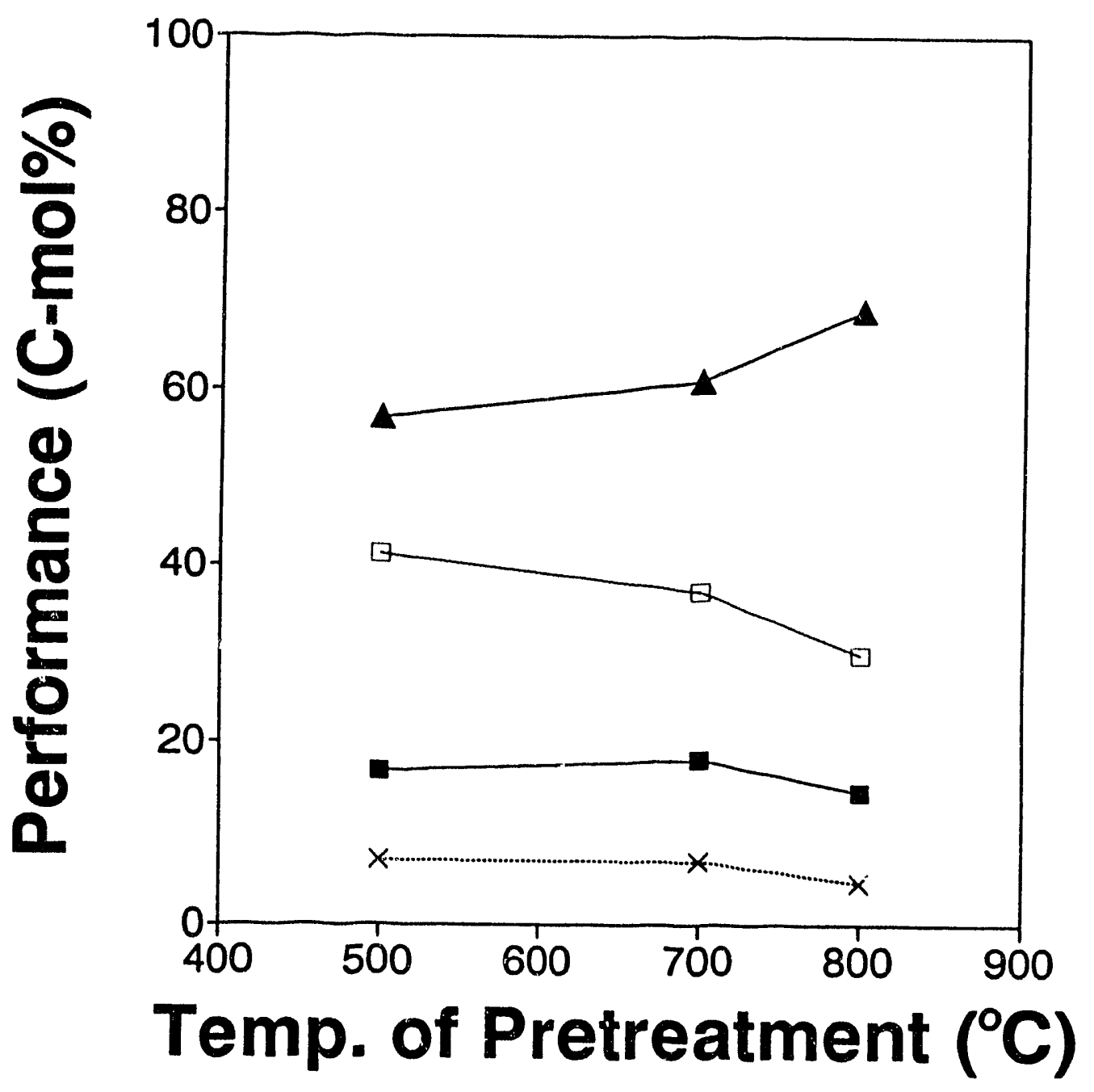

FIGURE 1

Effect of pretreatment in air at various temperatures on the catalytic performance of $1 \mathrm{wt} \%$ $\mathrm{SO}_{4}{ }^{2-} / 1 \mathrm{wt} \% \mathrm{Sr} / \mathrm{La}_{2} \mathrm{O}_{3}(0.1000 \mathrm{~g})$ in the oxidative coupling of $\mathrm{CH}_{4}$. Reaction temperature $=500^{\circ} \mathrm{C}$; reaction mixture of $\mathrm{CH}_{4} /$ air $=1 / 1 ;$ total pressure $=1 \mathrm{~atm} ; \mathrm{GHSV}=70,000$ $\ell / \mathrm{kg}$ catal $/ \mathrm{hr}$. (a) $\mathrm{CH}_{4}$ conversion ( $\square$, solid line); (b) $\mathrm{C}_{2}+$ selectivity ( $\square$, dotted line); (c) $\mathrm{CO}_{\mathrm{x}}$ selectivity ( 4 , solid line); and $(e) \%$ yield of $\mathrm{C}_{2}+(\mathrm{x}$, dashed line). 


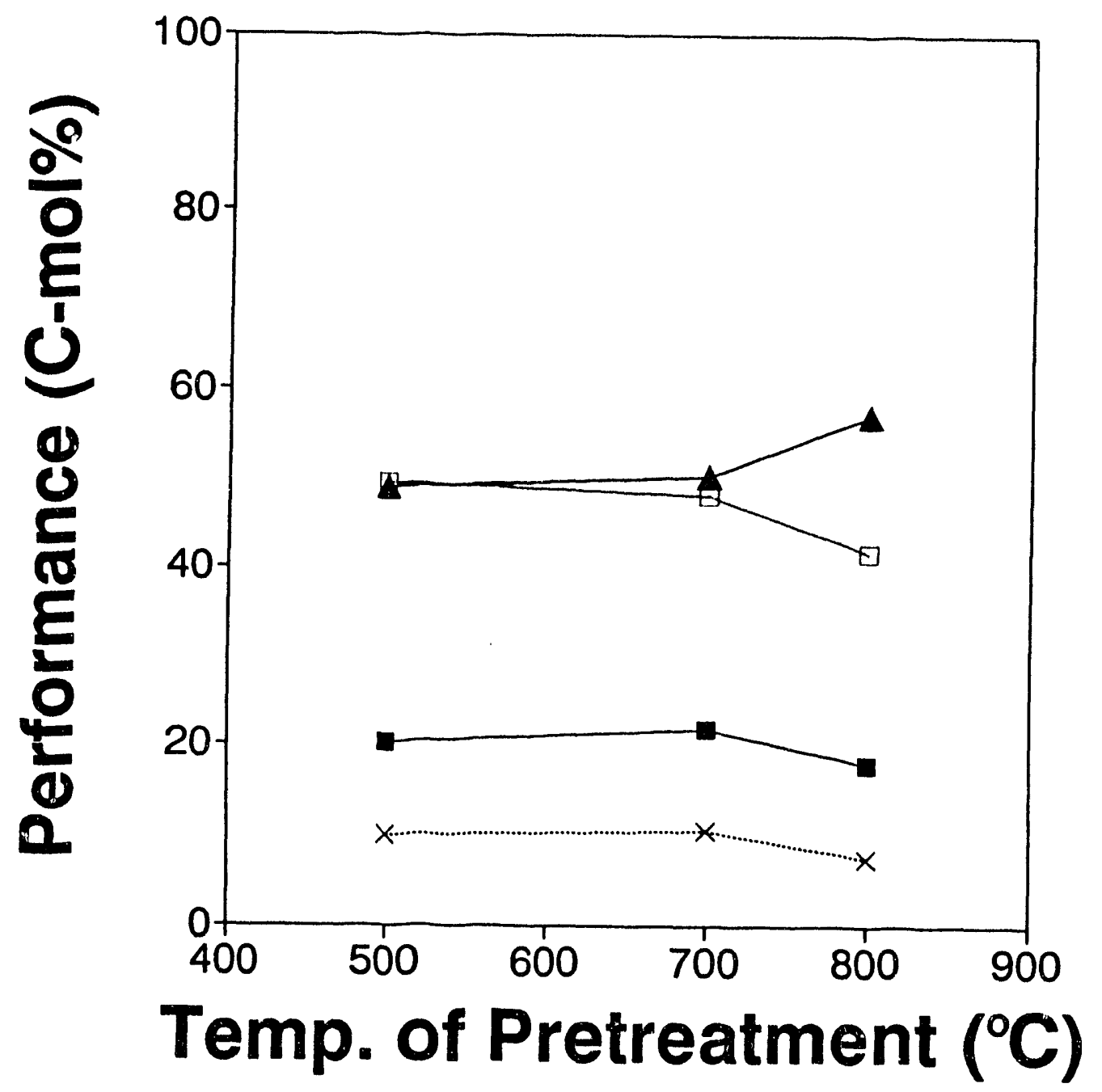

FIGURE 2

Effect of pretreatment in air at various temperatures on the catalytic performance of $1 \mathrm{wt} \%$ $\mathrm{SO}_{4}{ }^{2-} / 1 \mathrm{wt} \% \mathrm{Sr} / \mathrm{La}_{2} \mathrm{O}_{3}(0.1000 \mathrm{~g})$ in the oxidative coupling of $\mathrm{CH}_{4}$. Reaction temperature $=550{ }^{\circ} \mathrm{C}$; reaction mixture of $\mathrm{CH}_{4} /$ air $=1 / 1$; total pressure $=1 \mathrm{~atm} ; \mathrm{GHSV}=70,000$ $\ell / \mathrm{kg}$ catal $/ \mathrm{hr}$. (a) $\mathrm{CH}_{4}$ conversion ( $\mathrm{B}$, solid line); (b) $\mathrm{C}_{2}+$ selectivity ( $\square$, dotted line); (c) $\mathrm{CO}_{x}$ selectivity (^, solid line); and (e) \%yield of $\mathrm{C}_{2}+(x$, dashed line). 


\section{TABLE 2}

Effect of pretreatment on the catalytic performance of $1 \mathrm{wt} \% \mathrm{SO}_{4}{ }^{2-} / 1 \mathrm{wt} \% \mathrm{Sr} / \mathrm{La}_{2} \mathrm{O}_{3}$ $(0.1000 \mathrm{~g})$ in the oxidative coupling of $\mathrm{CH}_{4}$ with air (reactant mixture of $\mathrm{CH}_{4} /$ air $=1 / 1$; total pressure $=1 \mathrm{~atm} ;$ and GHSV $=70,000 \mathrm{\ell} / \mathrm{kg}$ catal $/ \mathrm{hr}$ )

Reaction Temperature $\left({ }^{\circ} \mathrm{C}\right)$

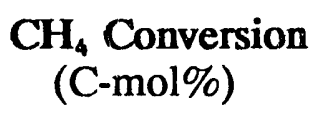

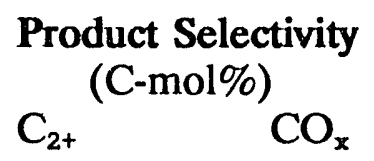

Yield of $\mathbf{C}_{2+}$

(C-mol\%)

(A) After the pretreatment in air at $500^{\circ} \mathrm{C}$ for $1 \mathrm{hr}$ (Standard Pretreatment)

$\begin{array}{lllll}500 & 16.77 & 41.37 & 56.77 & 6.94 \\ 550 & 20.16 & 49.40 & 48.82 & 9.96\end{array}$

(B) After the pretreatment in air at $700^{\circ} \mathrm{C}$ for $1 \mathrm{hr}$

$\begin{array}{lllll}500 & 17.97 & 36.95 & 60.76 & 6.64 \\ 550 & 21.72 & 47.90 & 50.02 & 10.41\end{array}$

(C) After the pretreatment in air at $800^{\circ} \mathrm{C}$ for $1 \mathrm{hr}$

$\begin{array}{lllll}500 & 14.43 & 29.91 & 68.90 & 4.32 \\ 550 & 17.84 & 41.68 & 56.98 & 7.44\end{array}$

(D) After the pretreatment in $\mathrm{He}$ at $500^{\circ} \mathrm{C}$ for $1 \mathrm{hr}$

$\begin{array}{lllll}500 & 16.27 & 36.10 & 62.22 & 5.87 \\ 550 & 20.24 & 48.38 & 49.94 & 9.79\end{array}$

(E) After the pretreatment in $\mathrm{He}$ at $700^{\circ} \mathrm{C}$ for $1 \mathrm{hr}$

$\begin{array}{lllll}500 & 15.62 & 32.48 & 66.01 & 5.07 \\ 550 & 19.16 & 42.67 & 55.43 & 8.18\end{array}$

(F) After the pretreatment in $\mathrm{He}$ at $800^{\circ} \mathrm{C}$ for $1 \mathrm{hr}$

$\begin{array}{lllll}500 & 14.34 & 31.24 & 67.14 & 4.48 \\ 550 & 18.36 & 42.39 & 56.22 & 7.78\end{array}$

Note: New catalyst was used in each experiment. 


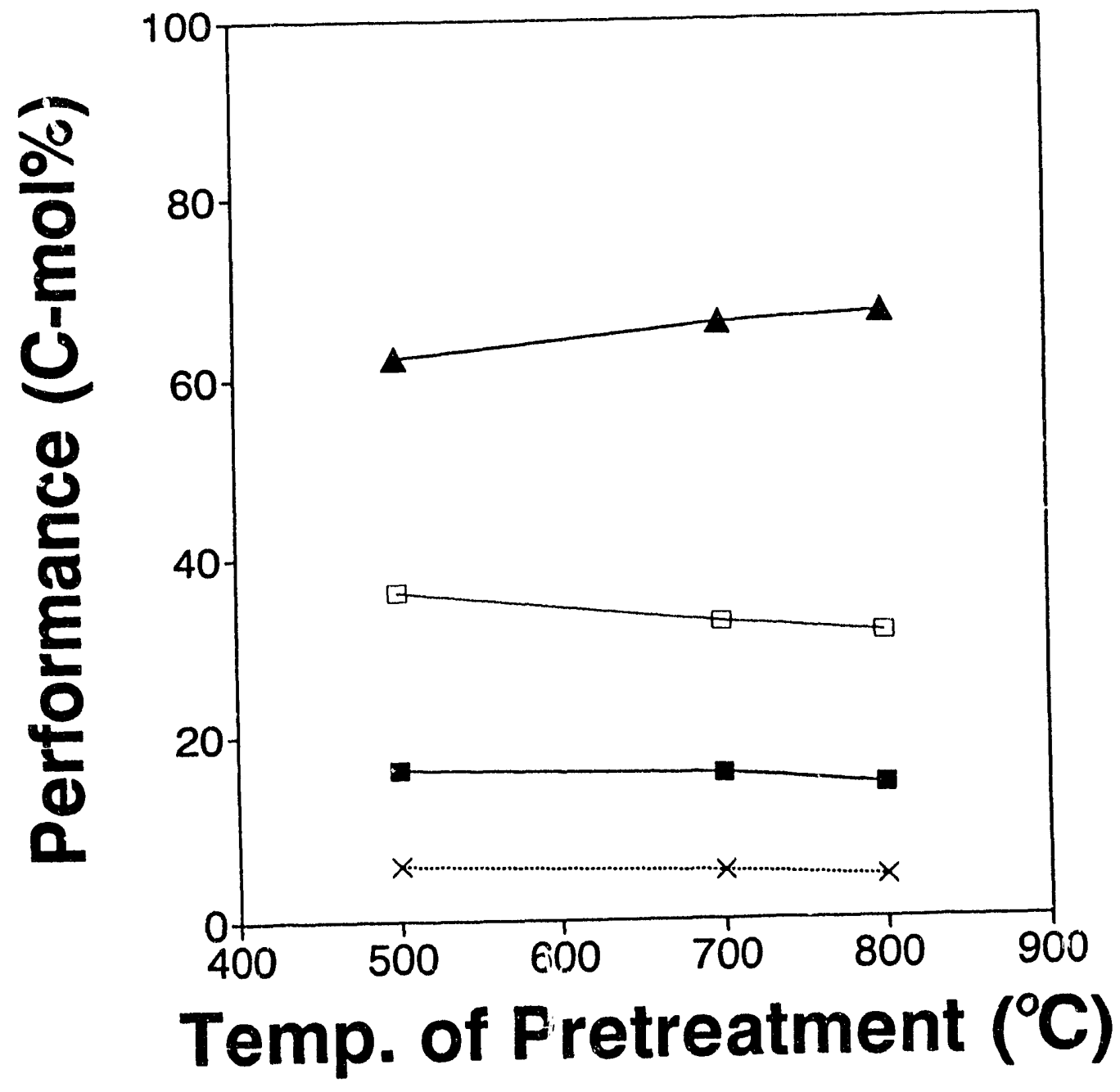

FIGURE 3

Effect of pretreatment in He at various temperatures on the catalytic performance of $1 \mathrm{wt} \%$ $\mathrm{SO}_{4}{ }^{2-} / 1 \mathrm{wt} \% \mathrm{Sr} / \mathrm{La}_{2} \mathrm{O}_{3}(0.1000 \mathrm{~g})$ in the oxidative coupling of $\mathrm{CH}_{4}$. Reaction temperature $=500{ }^{\circ} \mathrm{C}$; reaction mixture of $\mathrm{CH}_{4} /$ air $=1 / 1$; total pressure $=1 \mathrm{~atm} ;$ GHSV $=70,000$ $\ell / \mathrm{kg}$ catal/hr. (a) $\mathrm{CH}_{4}$ conversion ( $\square$, solid line); (b) $\mathrm{C}_{2}+$ selectivity ( $\square$, dotted line); (c) $\mathrm{CO}_{x}$ selectivity ( $\wedge$, solid line); and (e) \%yield of $\mathrm{C}_{2}+(\mathrm{x}$, dashed line). 


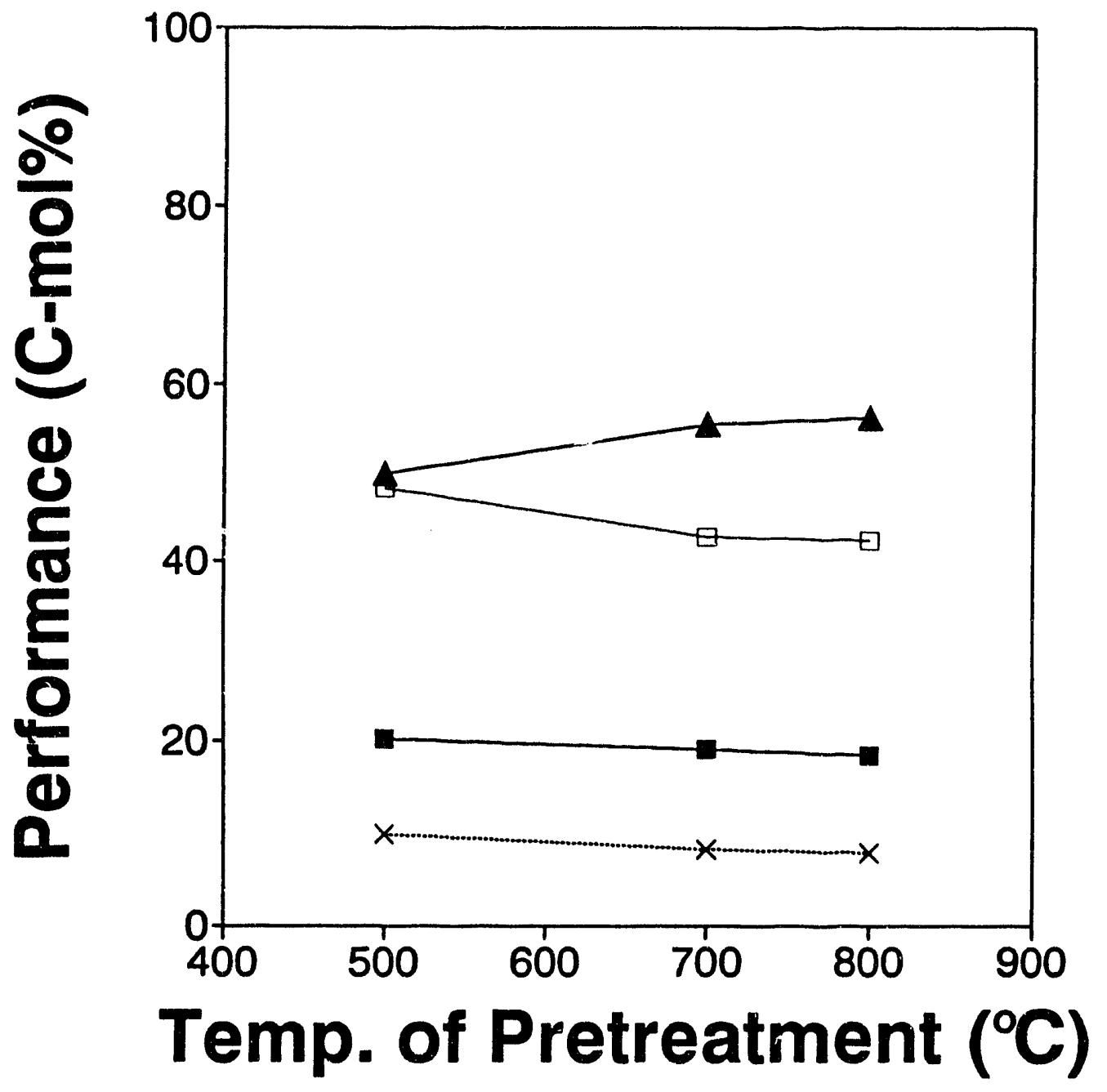

FIGURE 4

Effect of pretreatment in $\mathrm{He}$ at various temperatures on the catalytic performance of $1 \mathrm{wt} \%$ $\mathrm{SO}_{4}{ }^{2-} / 1 \mathrm{wt} \% \mathrm{Sr} / \mathrm{La}_{2} \mathrm{O}_{3}(0.1000 \mathrm{~g})$ in the oxidative coupling of $\mathrm{CH}_{4}$. Reaction temperature $=550{ }^{\circ} \mathrm{C}$; reaction mixture of $\mathrm{CH}_{4} /$ air $=1 / 1$; total pressure $=1 \mathrm{~atm}$; GHSV $=70,000$ e/kg catal/hr. (a) $\mathrm{CH}_{4}$ conversion ( $\square$, solid line); (b) $\mathrm{C}_{2}+$ selectivity ( $\square$, dotted line); (c) $\mathrm{CO}_{x}$ selectivity ( 4 , solid line); and (e) \%yield of $\mathrm{C}_{\bar{z}}+(\mathrm{x}$, dashed line). 
a GHSV $=70,175 \ell / \mathrm{kg}$ catal $/ \mathrm{hr}$, which was then decreased stepwise. As the GHSV was diminished to $17,120 \mathrm{\ell} / \mathrm{kg}$ catal $/ \mathrm{hr}$, the $\mathrm{CH}_{4}$ conversion gradually decreased from 15.38 to 6.79 C-mol\% (Figure 5(a)); the $\mathrm{C}_{2}{ }^{+}$selectivity decreased from 35.50 to $5.01 \mathrm{C}$-mol\% (Figure 6(a)), but the $\mathrm{CO}_{x}$ selectivity increased from 62.63 to $94.68 \mathrm{C}$-mol\% (Figure 7(a)). The $\mathrm{C}_{2}^{+}$ \%yield, of course, also decreased rapidly, i.e. from 5.46 to $0.34 \mathrm{C}$-mol\% (Figure 8(a)). Upon decreasing the GHSV further to $5,388 \mathrm{\ell} / \mathrm{kg}$ catal $/ \mathrm{hr}$, the $\mathrm{CH}_{4}$ conversion surprisingly increased to $8.27 \mathrm{C}$-mol\%, while the other catalytic parameters decreased (Figures 5-8, curves a). In this case, conversion of methane to only $\mathrm{CO}_{x}(99.4 \mathrm{C}-$ mol\%) was obtained, i.e. the catalyst was practically deactivated towards $\mathrm{C}_{2}^{+}$formation (Residence-Time-CausedDeactivation, RTCD).

When the flow rate was increased stepwise, the catalytic features changed to the opposite direction (Figures 5-8, curves b), but in each case a hysteresis was observed (Residence-Time-Hysteresis, RTH). Going back to the original GHSV $=70,175 \ell / \mathrm{kg}$ catal/hr, the $\mathrm{CH}_{4}$ conversion, the $\mathrm{C}_{2}{ }^{+}$selectivity, and the \%yield of $\mathrm{C}_{2}{ }^{+}$increased to 11.27, 18.31, and $2.06 \mathrm{C}$-mol\%, respectively, while the $\mathrm{CO}_{x}$ selectivity decreased to $80.00 \mathrm{C}$-mol\%.

These experimental results suggest that the entire oxidative coupling reaction of $\mathrm{CH}_{4}$ is a very complex process. It is considered that the $\cdot \mathrm{CH}_{3}$ radicals form by an $\cdot \mathrm{H}$ radical abstraction induced by surface oxygen species [20-23]. The $\cdot \mathrm{CH}_{3}$ radicals, being very weakly adsorbed species, get into the gaseous phase. Their recombination in the gas phase results in the formation of $\mathrm{C}_{2} \mathrm{H}_{6}$.

The contact catalytic formation of $\cdot \mathrm{CH}_{3}$ radicals needs higher temperature (e.g. $500^{\circ} \mathrm{C}$ or higher). However, once $\cdot \mathrm{CH}_{3}$ radicals exist in the gas phase, their recombination to $\mathrm{C}_{2} \mathrm{H}_{6}$, unlike the reaction steps of deeper oxidation, does not require an activation energy. Hence, the recombination is favorable at lower temperature, and the deeper oxidation to $\mathrm{CO}$ and $\mathrm{CO}_{2}$ if favored at high temperature. Low GHSV (high residence time) provides a longer time interval for the non-desirable deeper oxidation. However, in the case of high GHSV (low residence time), the gas mixture rapidly leaves the heated part of the reactor and cools down. Hence, the coupling reactions become more favorable relative to the deeper oxidations, i.e. more $\mathrm{C}_{2} \mathrm{H}_{6}$ and $\mathrm{C}_{2} \mathrm{H}_{4}$, but less $\mathrm{CO}$ and $\mathrm{CO}_{2}$ in the reaction products (selectivity problem). At low GHSV, the large amount of $\mathrm{CO}_{2}$ formed possibly poisons the active surface of the zatalyst by surface carbonates, and this decreases the possibility of - $\mathrm{CH}_{3}$ radical formation [19], i.e. the total $\mathrm{CH}_{4}$ conversion (activity problem).

\subsubsection{Reactivation - Effect of Higher Temperature}

\section{(A) Increase of Temperature}

After the RTH experiments described above and with GHSV restored to its original value $(70,175 \mathrm{\ell} / \mathrm{kg}$ catal $/ \mathrm{hr})$, the catalytic performance still remained in a deactivated stage (Figures 5-8), and the $\mathrm{C}_{2}^{+}$production remained at a low level. To overcome this deactivated state, the temperature was increased stepwise at constant GHSV $(70,175 \mathrm{l} / \mathrm{kg} \mathrm{catal} / \mathrm{hr})$ and $\mathrm{CH}_{4} /$ air $=1 / 1$ ratio beginning at $550^{\circ} \mathrm{C}$. $\mathrm{Up}$ to $580^{\circ} \mathrm{C}$, the $\mathrm{CH}_{4}$ conversion slowly increased 


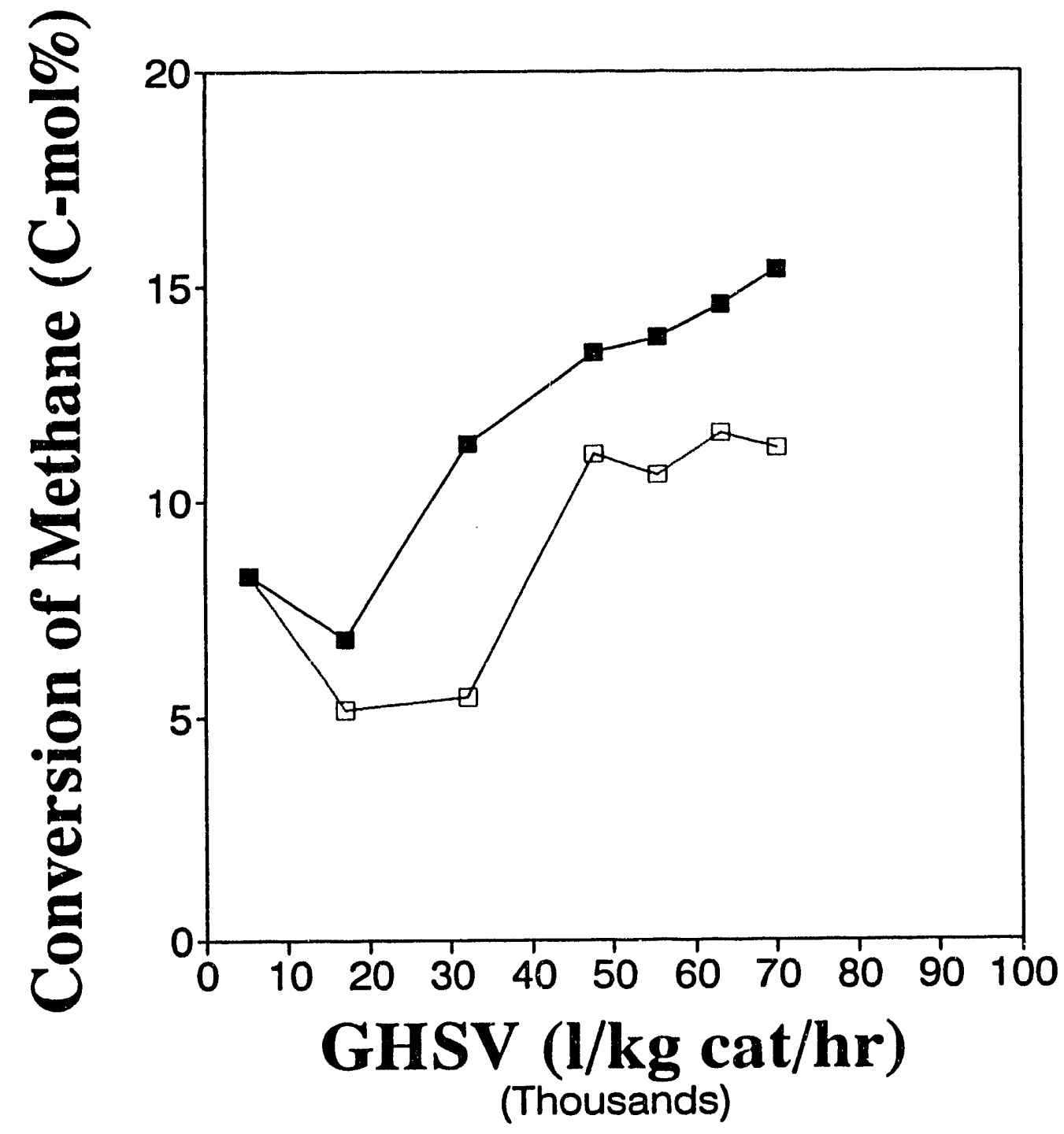

FIGURE 5

Effect of total flow rate on methane conversion at $550{ }^{\circ} \mathrm{C}$ over $1 \mathrm{wt} \% \mathrm{SO}_{4}{ }^{2-} / 1 \mathrm{wt} \%$ $\mathrm{Sr} / \mathrm{La}_{2} \mathrm{O}_{3}$ catalyst $(0.1000 \mathrm{~g})$ with a constant $\mathrm{CH}_{4} /$ air $=1 / 1$ reaction mixture at a total pressure of $1 \mathrm{~atm}$, and with (a) decreasing ( $\square$, solid line) and (b) increasing ( $\square$, dashed line) flow rates. GHSV was changed in a stepwise manner from 70,175 to $5,388 \mathrm{l} / \mathrm{kg}$ catal $/ \mathrm{hr}$ and then the procedure was reversed. 


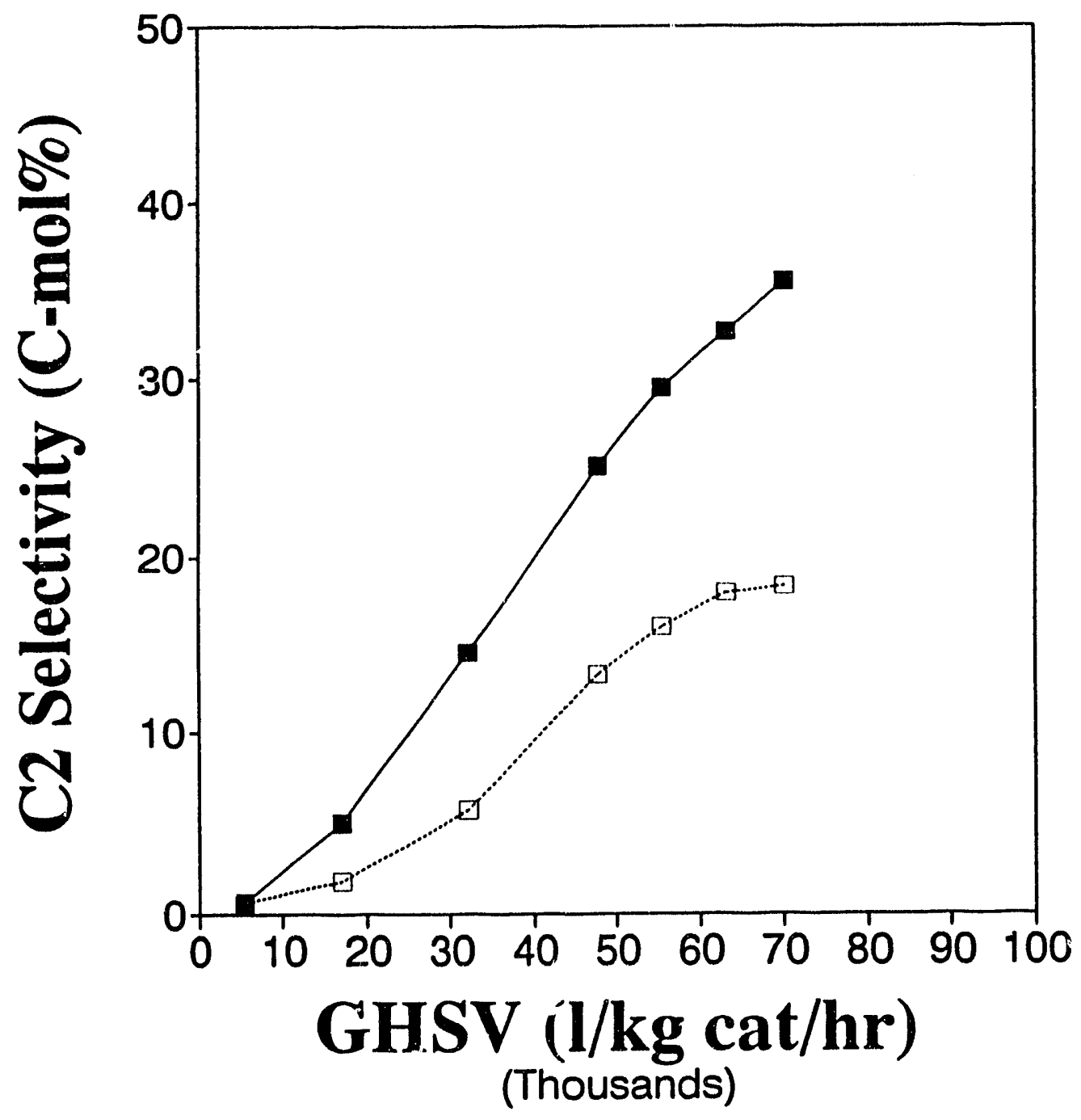

FIGURE 6

Effect of total flow rate on $\mathrm{C}_{2}+$ selectivity at $550^{\circ} \mathrm{C}$ over $1 \mathrm{wt} \% \mathrm{SO}_{4}{ }^{2-} / 1 \mathrm{wt} \% \mathrm{Sr} / \mathrm{La}_{2} \mathrm{O}_{3}$ catalyst $(0.1000 \mathrm{~g})$ with a constant $\mathrm{CH}_{4} /$ air $=1 / 1$ reaction mixture at a total pressure of 1 atm, and with (a) decreasing ( $\square$, solid line) and (b) increasing ( $\square$, dashed line) flow rates. GHSV was changed in a stepwise manner from 70,175 to $5,388 \mathrm{l} / \mathrm{kg}$ catal $/ \mathrm{hr}$ and then the procedure was reversed. 


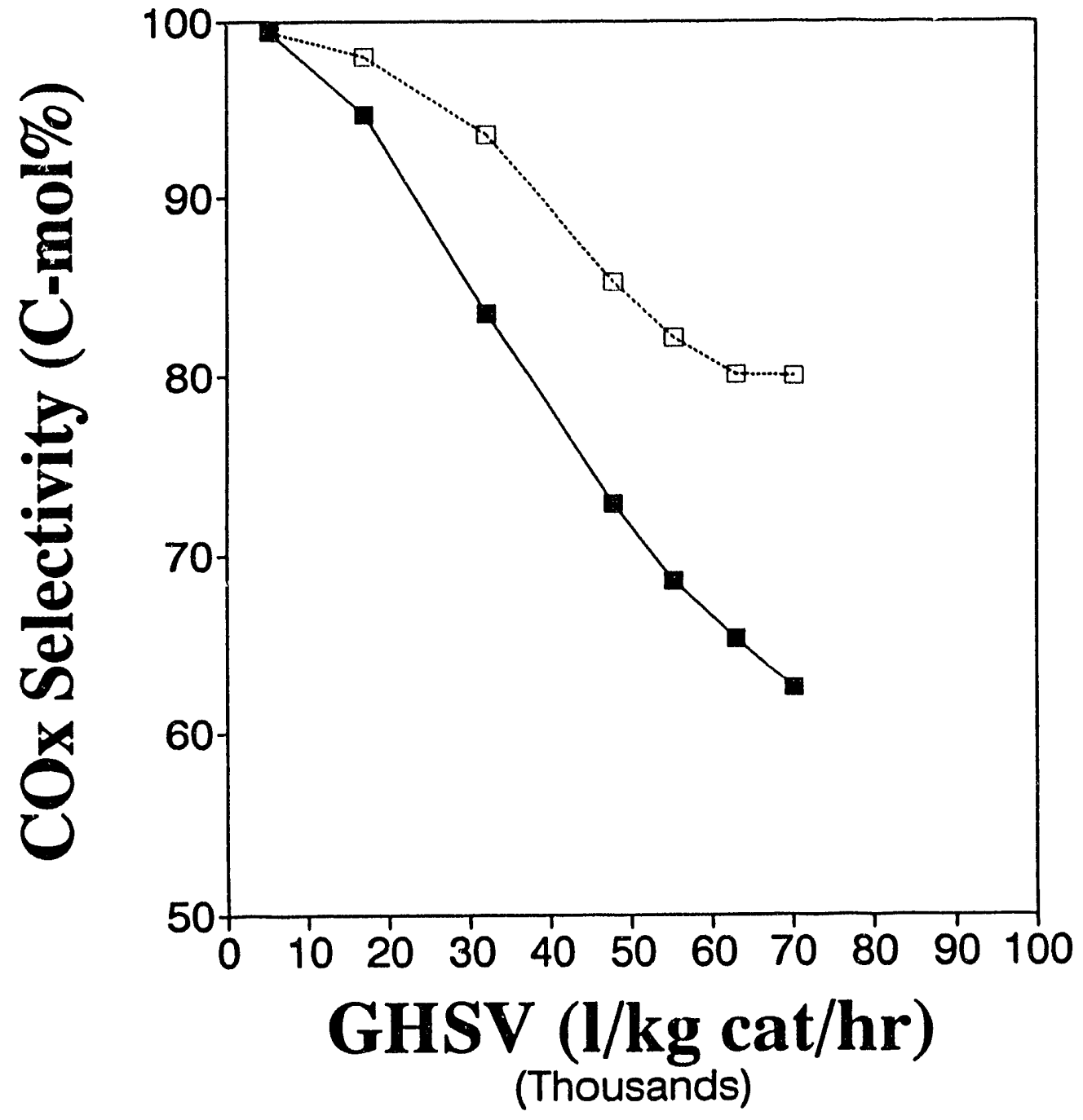

FIGURE 7

Effect of total flow rate on $\mathrm{CO}_{\mathrm{z}}$ selectivity at $550{ }^{\circ} \mathrm{C}$ over $1 \mathrm{wt} \% \mathrm{SO}_{4}{ }^{2-} / 1 \mathrm{wt} \% \mathrm{Sr} / \mathrm{La}_{2} \mathrm{O}_{3}$ catalyst $(0.1000 \mathrm{~g})$ with a constant $\mathrm{CH}_{4} /$ air $=1 / 1$ reaction mixture at a total pressure of 1 $\mathrm{atm}$, and with (a) decreasing ( $\square$, solid line) and (b) increasing ( $\square$. Jashed line) flow rates. GHSV was changed in a stepwise manner from 70,175 to $5,388 \mathrm{\ell} / \mathrm{kg}$ catal $/ \mathrm{hr}$ and then the procedure was reversed. 


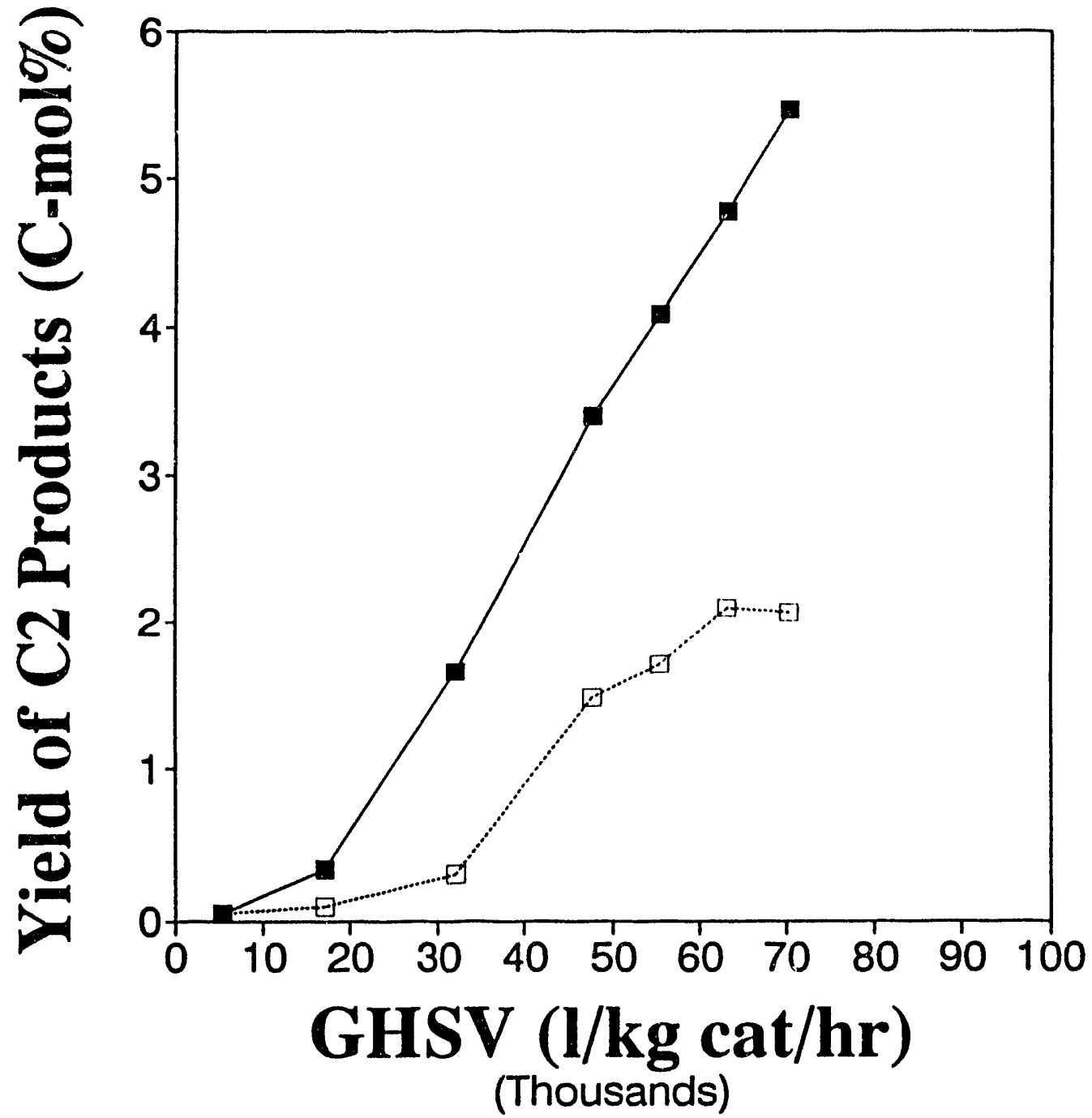

FIGURE 8

Effect of total flow rate on $\mathrm{C}_{2}+$ yield at $550{ }^{\circ} \mathrm{C}$ over $1 \mathrm{wt} \% \mathrm{SO}_{4}{ }^{2-} / 1 \mathrm{wt} \% \mathrm{Sr} / \mathrm{La}_{2} \mathrm{O}_{3}$ catalyst $(0.1000 \mathrm{~g})$ with a constant $\mathrm{CH}_{4} /$ air $=1 / 1$ reaction mixture at a total pressure of $1 \mathrm{~atm}$, and with (a) decreasing ( $\square$, solid line) and (b) increasing ( $\square$, dashed line) flow rates. GHSV was changed in a stepwise manner from 70,175 to $5,388 \mathrm{\ell} / \mathrm{kg}$ catal $/ \mathrm{hr}$ and then the procedure was reversed. 
(Figure 9(a)), and then upon increasing the temperature further to $585^{\circ} \mathrm{C}$ the methane conversion suddenly jumped to a much higher activity (Temperature-Caused-Reactivation, TCR). Further increases in temperature from $585^{\circ} \mathrm{C}$ up to $600^{\circ} \mathrm{C}$ caused only gradual increases in $\mathrm{CH}_{4}$ conversion. This TCR effect was more pronounced when the changes in $\mathrm{C}_{2}^{+}$and $\mathrm{CO}_{\mathrm{x}}$ selectivities (Figures 10(a) and 11(a)), and in the \%yield of $\mathrm{C}_{2}^{+}$products (Figure 12(a)) are considered.

As it was discussed above, a possible cause of RTCD is the large concentration of $\mathrm{CO}_{2}$ formed by complete oxidation of $\mathrm{CH}_{4}$ caused by the high residence time. Although restoring GHSV at $550^{\circ} \mathrm{C}$ to the original value somewhat increased the activity and $\mathrm{C}_{2}^{+}$ selectivity, but the catalyst mainly remained in a deactivated form. Upon gradually increasing the reaction temperature, while the other experimental parameters were kept unaltered, it was observed that a critical temperature $\left(585^{\circ} \mathrm{C}\right)$ was reached where the catalytic activity and $\mathrm{C}_{2}$ selectivity suddenly increased. This could be due to an undesirable surface structure/composition changing or decomposing and suddenly transforming into a new, more reactive surface. This may be a reason of the fast improvement in the catalytic performance.

\section{(B) Decrease of Temperature}

Stepwise decreasing the reaction temperature from 600 to $530^{\circ} \mathrm{C}$ caused a gradual reversal of catalytic features without any sudden jumps (Figures 9-12, curves b). Herice, the variations in the catalytic features in a cycle of increase and subsequent decrease in the temperature above (Figures 9-12) revealed a hysteresis (Temperature-Hysteresis of Catalytic Performances, THCP). It was shown that once the catalyst deactivated at $550^{\circ} \mathrm{C}$ by low GHSV, the reactivation needs a reaction temperature higher than $550^{\circ} \mathrm{C}$ at $\mathrm{GHSV}=70,175$ $\ell / \mathrm{kg}$ catal $/ \mathrm{hr}$. However, once the catalyst is in an "active form", sudden deactivation does not take place at this high GHSV when the temperature is decreased from 600 to $530^{\circ} \mathrm{C}$.

Further catalytic experiments, elemental analyses and surface characterization studies are under way to get a better understanding of the "active", "deactivated", and "reactivation" processes in the oxidative methane coupling reaction during various experimental conditions. 


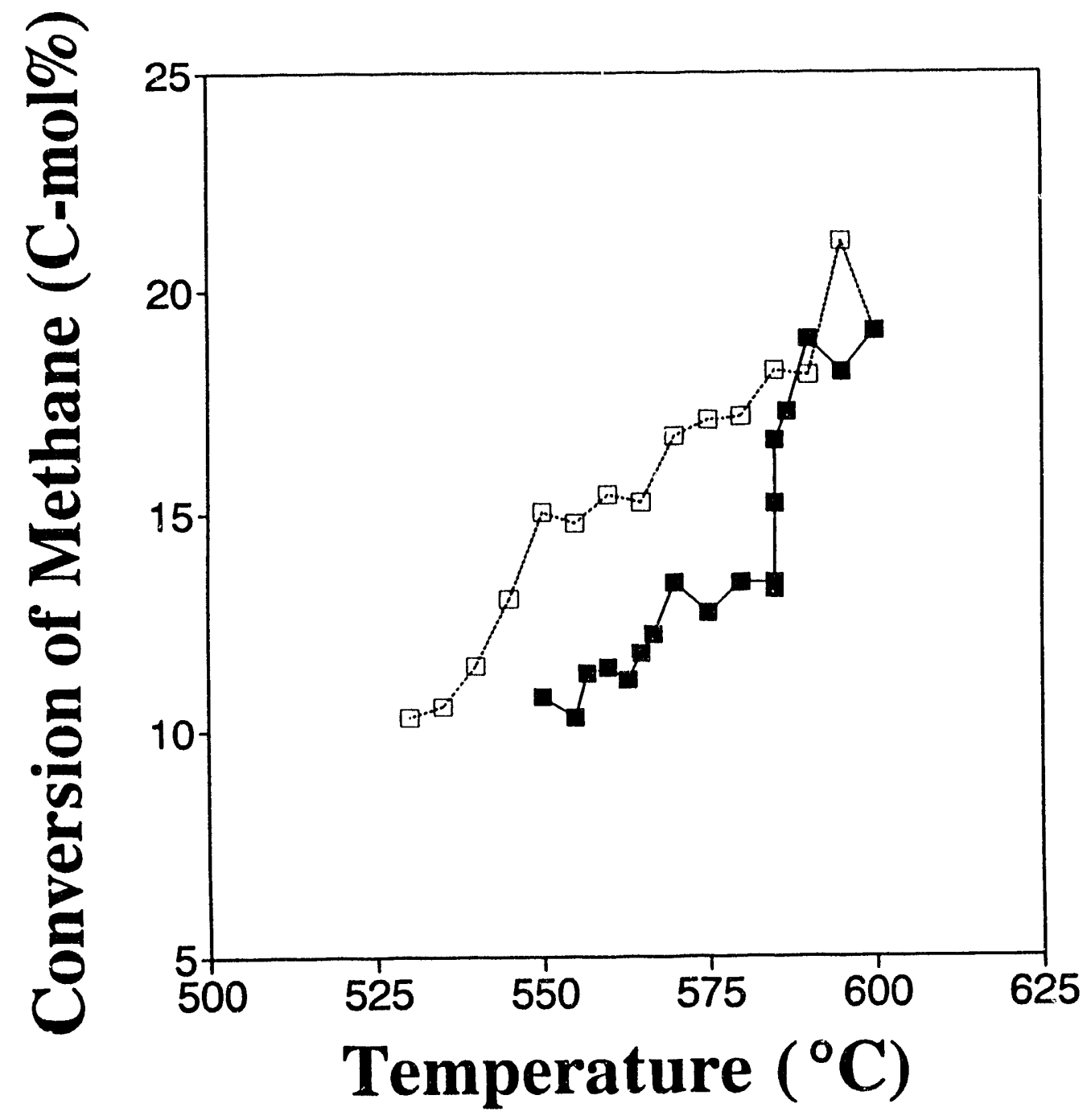

FIGURE 9

Effect of temperature on the conversion of $\mathrm{CH}_{4}$ over the deactivated $1 \mathrm{wt} \% \mathrm{SO}_{4}{ }^{2-} / 1 \mathrm{wt} \%$ $\mathrm{Sr} / \mathrm{La}_{2} \mathrm{O}_{3}$ catalyst $(0.1000 \mathrm{~g})$ with $\mathrm{CH}_{4} /$ air $=1 / 1$ reaction mixture at a total pressure of 1 $\mathrm{atm}$ and GHSV $=70,175 \mathrm{\ell} / \mathrm{kg}$ catal $/ \mathrm{hr}$. The reaction temperature was increased stepwise

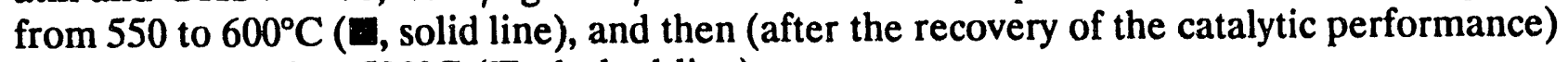
it was decreased to $530^{\circ} \mathrm{C}(\square$, dashed line). 


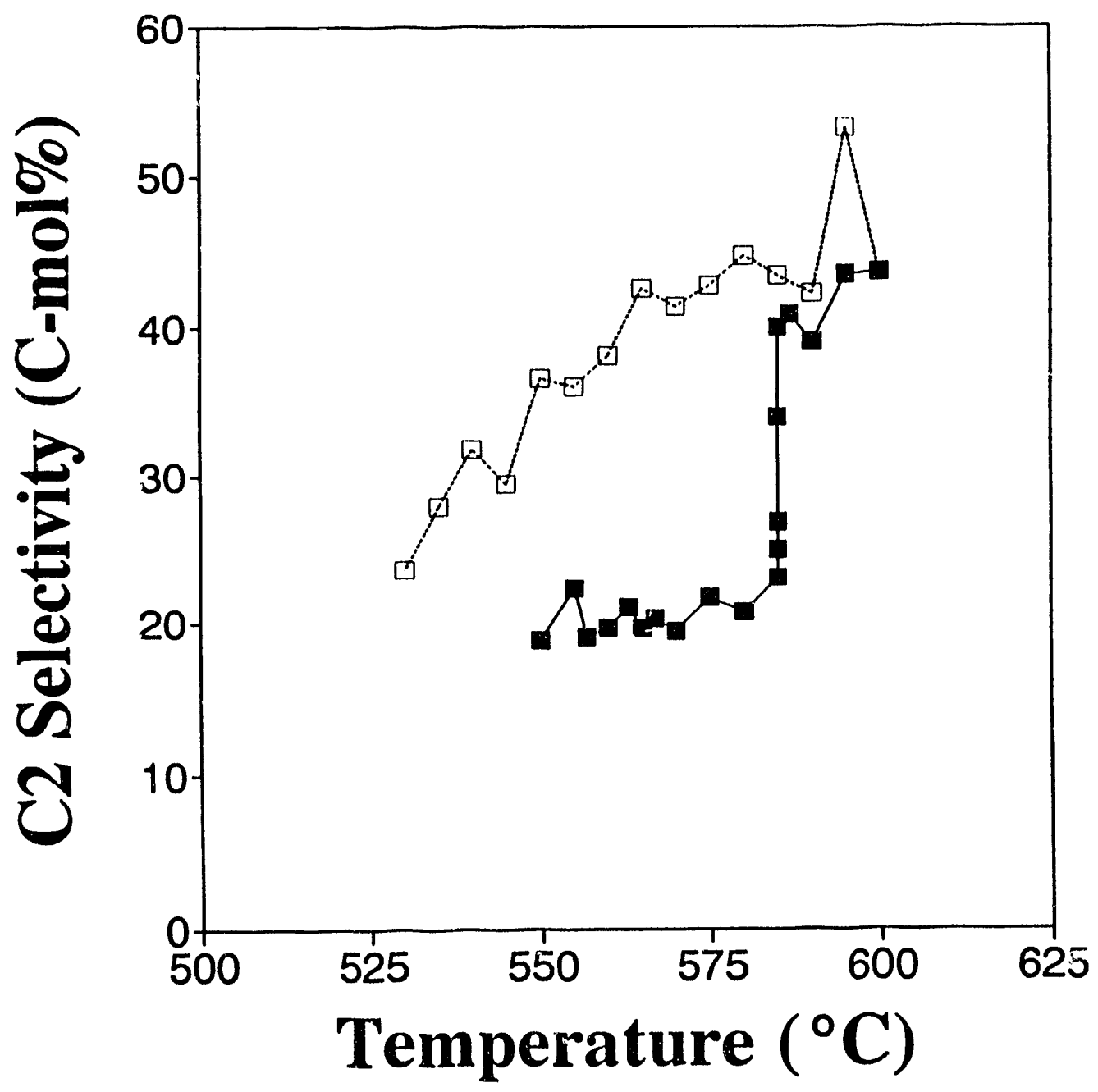

FIGURE 10

Effect of temperature on the $\mathrm{C}_{2}+$ selectivity from $\mathrm{CH}_{4}$ conversion over the deactivated 1 wt\% $\mathrm{SO}_{4}{ }^{2-} / 1$ wt $\% \mathrm{Sr} / \mathrm{La}_{2} \mathrm{O}_{3}$ catalyst $(0.1000 \mathrm{~g})$ with $\mathrm{CH}_{4} /$ air $=1 / 1$ reaction mixture at a total pressure of $1 \mathrm{~atm}$ and GHSV $=70,175 \mathrm{l} / \mathrm{kg}$ catal $/ \mathrm{hr}$. The reaction temperature was increased stepwise from 550 to $600^{\circ} \mathrm{C}$ ( 1 , solid line), and then (after the recovery of the catalytic performance) decreased to $530^{\circ} \mathrm{C}(\square$, dashed line). 


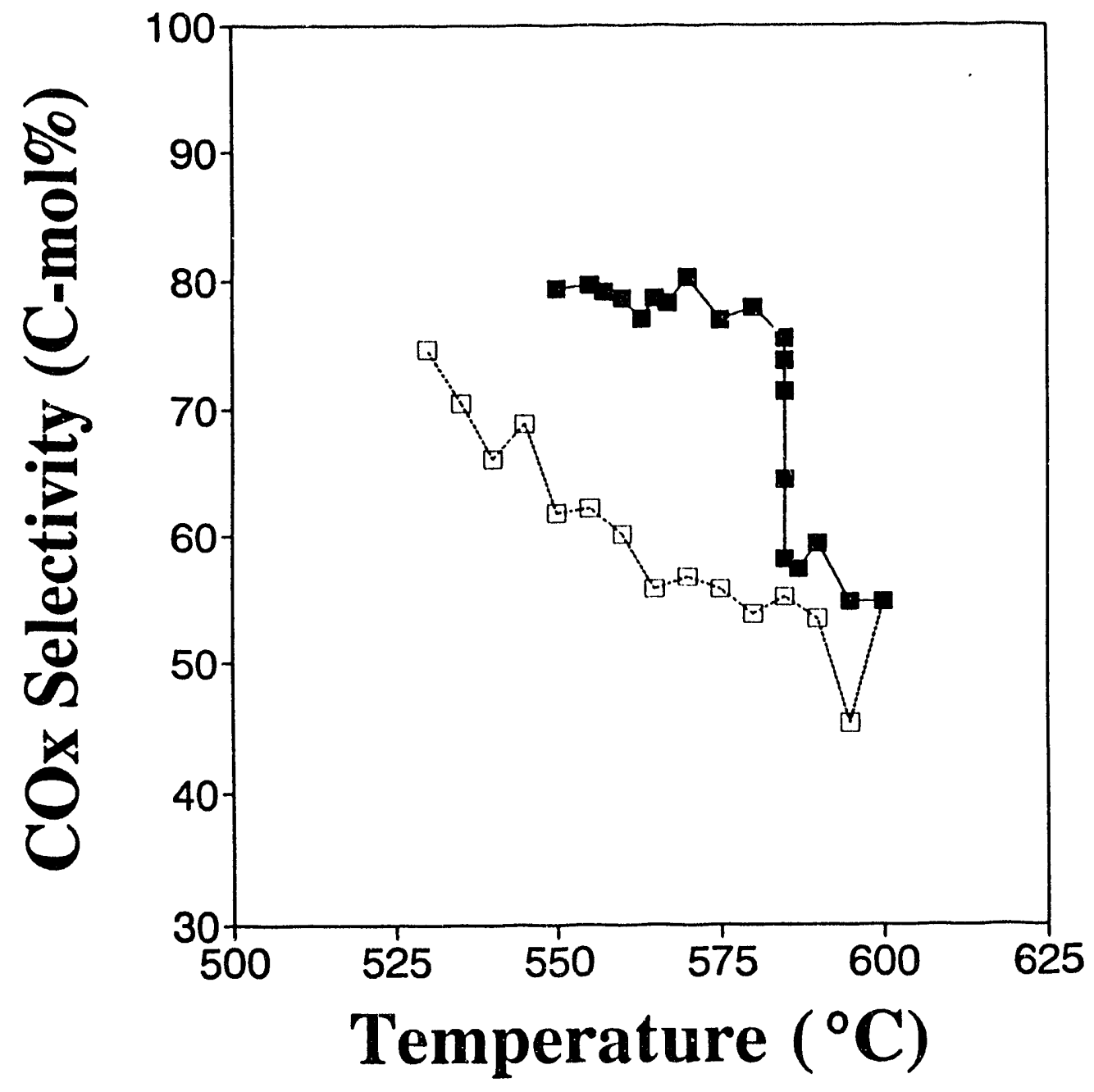

FIGURE 11

Effect of temperature on the $\mathrm{CO}_{\mathbf{x}}$ selectivity from $\mathrm{CH}_{4}$ conversion over the deactivated 1 wt\% $\mathrm{SO}_{4}{ }^{2-} / 1 \mathrm{wt} \% \mathrm{Sr} / \mathrm{La}_{2} \mathrm{O}_{3}$ catalyst $(0.1000 \mathrm{~g})$ with $\mathrm{CH}_{4} /$ air $=1 / 1$ reaction mixture at a total pressure of $1 \mathrm{~atm}$ and GHSV $=70,175 \mathrm{\ell} / \mathrm{kg}$ catal $/ \mathrm{hr}$. The reaction temperature was increased stepwise from 550 to $600^{\circ} \mathrm{C}(\square$, solid line), and then (after the recovery of the catalytic performance) decreased to $530^{\circ} \mathrm{C}(\square$, dashed line). 


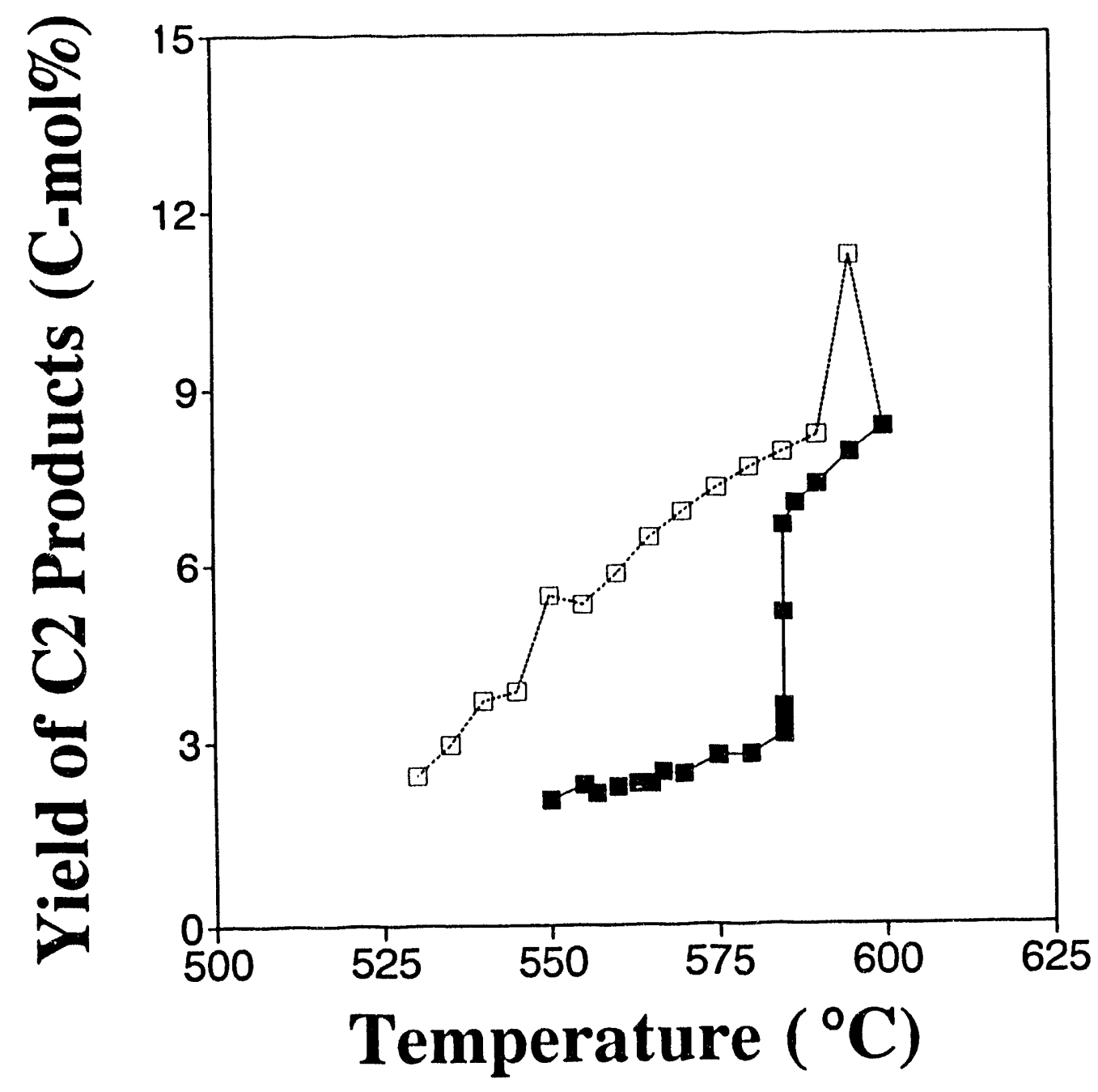

FIGURE 12

Effect of temperature on the \%yield of $\mathrm{C}_{2}+$ products from $\mathrm{CH}_{4}$ conversion over the deactivated $1 \mathrm{wt} \% \mathrm{SO}_{4}{ }^{2-} / 1 \mathrm{wt} \% \mathrm{Sr} / \mathrm{La}_{2} \mathrm{O}_{3}$ catalyst $(0.1000 \mathrm{~g})$ with $\mathrm{CH}_{4} /$ air $=1 / 1$ reaction mixture at a total pressure of $1 \mathrm{~atm}$ and GHSV $=70,175 \mathrm{\ell} / \mathrm{kg}$ catal $/ \mathrm{hr}$. The reaction temperature was increased stepwise from 550 to $600^{\circ} \mathrm{C}$ ( $\mathrm{a}$, solid line), and then (after the recovery of the catalytic performance) decreased to $530^{\circ} \mathrm{C}(\square$, dashed line). 


\section{References}

[1] G.E. Keller and M.M. Bhasin, J. Catal. 73 (1982) 9.

[2] N.R. Foster, Appl. Catal. 19 (1985) 1.

[3] H.D. Gesser, N.R. Hunter, and C.B. Prakash, Chem. Rev. 85 (1985) 235.

[4] R. Pitchai and K. Klier, Catal. Rev.-Sci. Eng. 28 (1986) 13.

[5] M.S. Scurrell, Appl. Catal. 32 (1987) 1.

[6] J.S. Lee and S.T. Oyama, Catal. Rev.-Sci. Eng. 30 (1988) 249.

[7] G.H. Hutchings, M.S. Scurrell, and J.R. Woodhouse, Chem. Soc. Rev. 18 (1989) 251.

[8] J.H. Lunsford, Catal. Today 6 (1990) 235.

[9] Y. Amenomiya, V.I. Birss, M. Goledzinowski, J. Galuska, and A.R. Sanger, Catal Rev.-Sci. Eng. 32 (1990) 163.

[10] J.C. Mackie, Catal. Rev.-Sci. Eng. 33 (1991) 169.

[11] J.H. Lunsford, in "Studies in Surface Science and Catalysis", Vol. 61: "Natural Gas Conversion" (A. Holmen, K.-J. Jens and S. Kolboe, Eds), Elsevier, New York, 1991, p. 3.

[12] H.B.A. Hamid and R.B. Moyes, Catal. Today 10 (1991) 267.

[13] J.M. Deboy and R.F. Hicks, J. Catal. 113 (1988) 517; J. Chem Soc., Chem. Commun. (1988) 982.

[14] T. LeVan, M. Che, and J.-M. Tatibouet, Catal. Lett. 14 (1992) 321.

[15] K. Klier, R.G. Herman, J. Sárkány, and Q. Sun, Quarterly Technical Progress Report DOE/MC/29288-2, March 1993, 19 pp.

[16] R.P. Taylor and G.L. Schrader, Ind. Eng. Chem. Res. 30 (1991) 1016.

[17] S.J. Conway, J.A. Greig, and G.M. Thomas, Appl. Catal. A, 86 (1992) 199.

[18] K.I. Aika and K. Aono, J. Chem. Soc., Faraday Trans., 87 (1991) 1273.

[19] M.-T. Xu and J.H. Lunsford, Catal. Lett., 11 (1991) 295. 
[20] K. Otsuka, K. Jinno and A. Morikawa, J. Catal. 100 (1986) 353.

[21] K.D. Kampbell, H. Zhang, and J.H. Lunsford, J. Phys. Chem. 92 (1988) 750.

[22] T. Ito, J.-X. Wang, C.-H. Lin, and J.H. Lunsford, J. Am. Chem. Soc. 107 (1985) 5062.

[23] C.-H. Lin, J.-X. Wang, and J.H. Lunsford, J. Catal. 111 (1988) 302. 

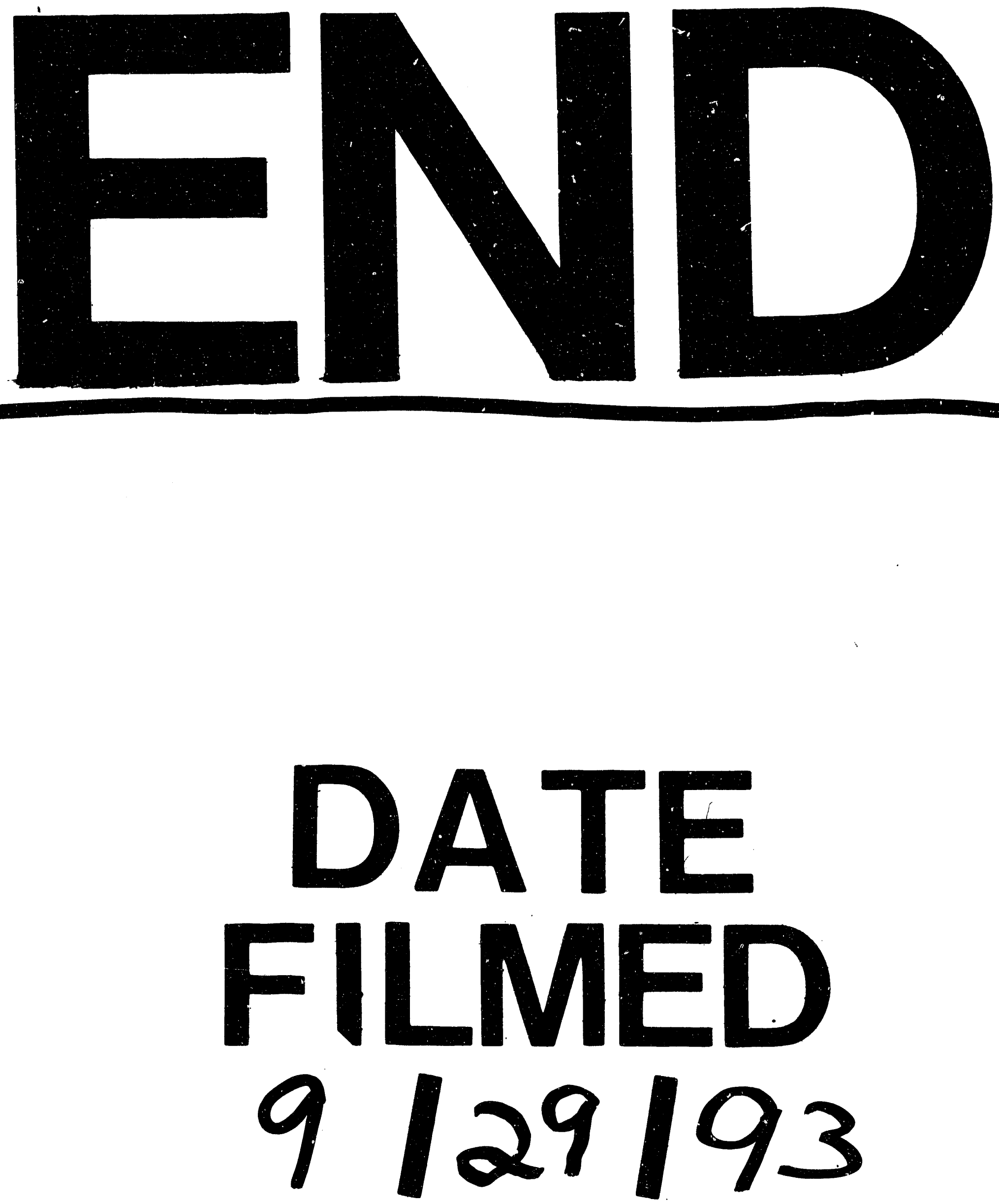